\title{
The problem of reproduction of basic assets in industry as the Barrier for neoindustrial transformation of regional economy
}

\author{
T.V. Mirolubova ${ }^{1, *}$, and E.N. Voronchikhina ${ }^{1}$ \\ ${ }^{1}$ Department of the World and Regional Economy, Economic Theory, Perm State National Research University, Perm, Russia
}

\begin{abstract}
Theoretical principles of neoindustrial transformation and basic assets reproduction have been studied in the article. It has been reviewed historical approaches to the disclosure of the examined conceptions for the purpose of defining the extent of every presented concept's reflection of the most important aspects in the analyzed categories. The authors considered one of the internal factors being an obstacle in the new way of Russian development - reproductive process of basic assets in industry. There have been determined the rates of investment growth in capital asset, the growth rates of capital renewals, and the growth rates of basic assets depreciation according to the types of industrial economic activity. There have been revealed general problems of regional industry development connected with reproduction of basic assets. The authors of the article have made a conclusion about the essential improvement of reproductive processes in the regional industry by means of parallel processes' stimulation: elimination of worn assets from the economic turnover and increase of investment in capital assets aimed at renewal of conventional production and conferring high-tech character to the fields identifying basic competencies of industrial region.
\end{abstract}

\section{Introduction}

Economic recession experienced by Russia today has revealed the problem of searching new directions of country's development as the most pressing one. The increase of the resource economy's share followed by deindustrialization resulted in decline of competitive strength of the native manufacturing industry. Thereupon, the task of renewal of industrial capital assets on basis of high-tech modernization is becoming particularly urgent. Manifestations of crisis in Russian economy are undoubtedly connected with changes in world oil market, with devaluation of national currency, with sanctions from Western countries, and etc. However, in the years of high oil rent nominally high growth rates of GDP were connected not with diversification of economy and conversion to high-tech and science intensive production but they were principally conditioned by hydrocarbons' stiff prices.

Therefore, economic situation today is connected not so much with external factors as with internal ones, namely with profound reasons of long-term character.

Such scientists as A.R.Belousov [1,2], S.Yu.Glazyev [3] and some others take the view of the fact that difficulties experienced by Russian economy have been caused by the internal reasons. This point of view found the reproduction in the annual President's message on the 4th of December 2014 [4].
At the present time the general strategic imperative of public policy consists in achievement of national economy's qualitative growth assuming its cardinal neoindustrial transformation. Theory principles of forming new industrialization as independent type of society transformation were hypothecated in the work of J.Helbreit about new industrial society [5], then they found continuation and development in works of D.Bell about post industrial society [6], in works of E.Toffler about super-industrial society $[7,8]$ and M. Castells on the information society [9] (Table I).

Neoindustrial paradigm as vector of national economy development has been considerably substantiated by S.S.Gubanov [10, 11]. The formula for development of Russia has been scientifically identified: neoindustrialization plus vertical integration. Neoindustrial reconstruction implies higher level of technological renewal of Russian productive forces, automation and computerization of all branches, and, first of all, of key, manufacturing industries. Conducting new industrialization as objectively ripen process is explained by the fact that it is exactly industry which provides high growth rates of labour production and makes positive multiplicative influence on the other sectors of economy. "The world of the XXI century continues to be the world of renewed but industrial society" $[12,13]$.

*Corresponding author: mirolubov@list.ru 
Table 1. Theoretical principles of neoindustrial transformation.

\begin{tabular}{|c|c|}
\hline Scientists, main works & General ideas \\
\hline \multicolumn{2}{|c|}{ Historical review } \\
\hline $\begin{array}{c}\text { Helbreit J.K. } \\
\text { "New industrial society" (1967) }\end{array}$ & $\begin{array}{l}\text { Modern capitalism (second half of the XX century) as "new industrial } \\
\text { society" the principle element of which - industrial system - is that } \\
\text { part of economy which is characterized by the existence of large } \\
\text { corporations. }\end{array}$ \\
\hline $\begin{array}{l}\text { Bell D. } \\
\text { "Forthcoming post industrial society" (1973) }\end{array}$ & $\begin{array}{l}\text { Substantiation of pre-industrial, industrial and post industrial society's } \\
\text { existence. Development of the last on the base of technological } \\
\text { determinism, i.e. historical process of society's development depends } \\
\text { on the level of industrial development. }\end{array}$ \\
\hline $\begin{array}{c}\text { Toffler E. } \\
\text { "Shock of the future"(1970), "The third wave" (1980) }\end{array}$ & $\begin{array}{l}\text { Futuristic concept of new society formation - "super industrial" } \\
\text { society. Special attention is given to the predictable trends of future } \\
\text { and to the problems of adaptation to those trends. }\end{array}$ \\
\hline $\begin{array}{c}\text { Kastels M. "Informational era", (monograph, three volumes, } \\
\text { 1996-1998) }\end{array}$ & $\begin{array}{l}\text { The concept of "informational society" in the base of which is new } \\
\text { information-technological paradigm. }\end{array}$ \\
\hline \multicolumn{2}{|c|}{ Modern studies } \\
\hline $\begin{array}{c}\text { Gubanov S.S. } \\
\text { "Sovereign break. Neo-industrialization of Russia and } \\
\text { vertical integration" (2012) }\end{array}$ & $\begin{array}{l}\text { Formula of new Russian development direction: neo-industrialization } \\
\text { plus vertical integration. }\end{array}$ \\
\hline $\begin{array}{l}\text { Afontsev S.A., Galushka A.S., Golubovich A.D., Dmitriev } \\
\text { M.G., Idrisov A.B., Osipov A., Pototsky I.V., Titov B.Yu., } \\
\text { Shpigel V.V., Yuryev E.L. (All-Russian public organization } \\
\text { named "Business Russia") "New industrialization. Concept } \\
\text { 25X25" Plan" (2011) }\end{array}$ & $\begin{array}{l}\text { CPI: creation of } 25 \text { million new modern high productive workplaces } \\
\text { in competitive sector at the expense of priority development of non- } \\
\text { resource processing industries of the national economy by } 2025 \text {-just } \\
\text { "new industrialization". }\end{array}$ \\
\hline $\begin{array}{l}\text { Bodrunov S.D., Lopatin V.N., Okrepilov V.V. (Institute of } \\
\text { New Industrial Development) } \\
\text { "Re-industrialization of Russia: improvement of public } \\
\text { administration, legal and technological regulation" (2013) }\end{array}$ & $\begin{array}{l}\text { Algorithm of activity aimed at consolidation of public administration } \\
\text { mechanisms and scientific-technological progress and innovative } \\
\text { development of Russia in the process o formation and realization of } \\
\text { public policy. }\end{array}$ \\
\hline $\begin{array}{c}\text { Coombs R. Miles I. (University of Manchester) } \\
\text { "Innovations, measurement and services: modern range of } \\
\text { problems" (2000) } \\
\text { Barras R. (University of Manchester) } \\
\text { "Theory of innovative activity in service industries" (1986) }\end{array}$ & $\begin{array}{l}\text { Problems of service industries in the frames of modern industrial } \\
\text { model of development. Product innovations in service industries have } \\
\text { "inverse life-cycle". It begins with the use of new technologies aimed } \\
\text { at improvement of productive efficiency and finishes by creation of } \\
\text { new services opposite to the cycle being the characteristic feature of } \\
\text { material production. }\end{array}$ \\
\hline $\begin{array}{l}\text { Tregenna F. (University of Johannesburg) } \\
\text { "Productivity, de-industrialization and re-industrialization" } \\
\text { (2011), "De-industrialization: analysis of employment and } \\
\text { turnout changes in processing industry" (2009) }\end{array}$ & $\begin{array}{l}\text { Analysis of de-industrialization problem in world economy in the } \\
\text { context of employment level changes in processing industries. De- } \\
\text { industrialization is considered to be steady decrease in the number of } \\
\text { processing industry workers and lowering part of processing industry } \\
\text { in GDP is mentioned. The importance of creating industrial policy } \\
\text { concept in the transition period from de-industrialization to re- } \\
\text { industrialization has been shown. }\end{array}$ \\
\hline $\begin{array}{l}\text { Sussan A. (International Business at Bethune - Cookman } \\
\text { University in Florida) } \\
\text { "Strategy of re-industrialization in world economy" (2012) }\end{array}$ & $\begin{array}{l}\text { In the frames of retail trade it is carried out the search of ability to } \\
\text { improve social-economic development. Study of modification of } \\
\text { competiveness substance and role of technologies. }\end{array}$ \\
\hline $\begin{array}{l}\text { Aryeetey-Attoh S., Lindquist P., Muraco W., Reid N. } \\
\text { (Cambridge University) } \\
\text { "Northwestern Ohio: re-industrialization and reduction of } \\
\text { harmful substances emission" (2003) }\end{array}$ & $\begin{array}{l}\text { Search of the ways of the greenhouse effect reduction due to } \\
\text { technological and structural changes. }\end{array}$ \\
\hline $\begin{array}{l}\text { Etzioni A. (George Washington University) } \\
\text { "Re-industrialization of America (2005) }\end{array}$ & $\begin{array}{l}\text { Social and psychological aspects of re-industrialization. It has been } \\
\text { selected seven components of high pace of economic development } \\
\text { and living standard - transport, communication, power, innovations, } \\
\text { labour resources, finance capital and means of production. }\end{array}$ \\
\hline $\begin{array}{l}\text { Westkämper E. (Universität Stuttgart) } \\
\text { "Re-industrialization of Europe: concept of processing } \\
\text { industry development up to 2030" (2014) }\end{array}$ & $\begin{array}{l}\text { General trends of social-economic development, problems of industry } \\
\text { development. It has been selected } 4 \text { key directions in the European } \\
\text { industrial strategy: industrial environmental pollution, ecologically } \\
\text { conscious production, cost-making chain, information awareness } \\
\text { communication. R\&D has been paid special attention. }\end{array}$ \\
\hline
\end{tabular}

One of the key problems in the process of realizing neoindustrialized transformation of Russia is the problem of basis assets' reproduction.

Basic assets correspond stocks of materials and capital equipment created in the process of production and used there on repeated occasions or permanently in unvaried natural-material form over a long period of time, persistently shifting their value to products and services [14].

Let's consider the approaches to the subject matter of industrial basic assets reproduction in order to determine the presented concepts' ability to reflect the most important aspects of the analyzed category (Table II). 
Table 2. Theoretical principles of industrial basic assets reproduction.

\begin{tabular}{|c|c|}
\hline $\begin{array}{l}\text { School of economic } \\
\text { thought/researchers }\end{array}$ & General ideas \\
\hline \multicolumn{2}{|r|}{ Historical review } \\
\hline $\begin{array}{l}\text { Mercantilism } \\
\text { (Man T., Monkrentyen } \\
\text { A.) }\end{array}$ & $\begin{array}{l}\text { The main source of capital accumulation defining the factor of economic development is foreign } \\
\text { trade. The principle form of wealth is money in the form of gold and silver; the idea of capital } \\
\text { accumulation is in the basis of the concept of reproduction }\end{array}$ \\
\hline $\begin{array}{c}\text { Physiocraty } \\
\text { (Kene F., Tyurgo R.) }\end{array}$ & $\begin{array}{l}\text { Power of nature in all spheres of activity. Reproductive processes of capital were considered } \\
\text { primarily in the field of agricultural production where additional product was created. There } \\
\text { appeared such notions as "rent", "net effective income", regulations of demand and supply } \\
\text { interaction. }\end{array}$ \\
\hline $\begin{array}{l}\text { Classical political } \\
\text { economy } \\
\text { (Smith A., Ricardo D.) }\end{array}$ & $\begin{array}{l}\text { Smith A. [15] selected basic and current capital in the structure of production capital. Capital } \\
\text { accumulation is the main condition for society's riches growth and the main source of } \\
\text { reproduction. } \\
\text { Ricardo D. analyzed the means of production. He thought that "the part of the country's wealth } \\
\text { which is used in production and consists food, cloths, instruments, raw materials, machines, etc., } \\
\text { is indispensable for work" but due to inequality of profit on invested capital the last "is displaced } \\
\text { from one activity to the other" [16]. }\end{array}$ \\
\hline $\begin{array}{c}\text { Marxism } \\
\text { (Marx K., Engels F.) }\end{array}$ & $\begin{array}{l}\text { Capital accumulation occurs in the process of production and the process of production “... } \\
\text { considered in stable connection and in continuous flow of its renewal is at the same time the } \\
\text { process of reproduction" [17]. Simple reproduction “....is the simple recurrence of production } \\
\text { process in constant scale" [17]. Extended reproduction presupposes systematic addition of the } \\
\text { definite part of surplus value to the functioning capital. K. Marx and F.Engels studied the } \\
\text { problems of capital replacement through the practice of specially assigned funds' formation, in } \\
\text { particular, fund of renewal [18]. }\end{array}$ \\
\hline $\begin{array}{l}\text { Marginalism } \\
\text { (Valras L.) }\end{array}$ & $\begin{array}{l}\text { Mathematical scheme of reproduction process description in which casual economic relations are } \\
\text { completely changed by the methods of quantitative functional analysis. In methodological aspect } \\
\text { L.Valras's theory inspired the efforts to present the process of social reproduction as organic } \\
\text { market mechanism of definite products' reproduction. }\end{array}$ \\
\hline \multicolumn{2}{|r|}{ Modern research } \\
\hline $\begin{array}{l}\text { Arakelyan A.A., Baranov } \\
\text { D.A., Kalinin V.P., } \\
\text { Kantor E.L., Kovalyov } \\
\text { A.F., Korkin S.K., } \\
\text { Kuzmenko S.M., Kushlin } \\
\text { V.I., Lyubimtsev V.I., } \\
\text { Malygin A.A., Pavlov } \\
\text { P.M., Rimer M.I., } \\
\text { Shulman S.I. } \\
\end{array}$ & $\begin{array}{l}\text { Problems of the enterprise's basic assets revolution, particularly, the problem of separation of the } \\
\text { original stage of reproduction process. D.A.Baranov [19], S.K.Korkin [20] think that the original } \\
\text { stage of funds motion in the process of basic assets reproduction is the productive one; } \\
\text { Yu.I.Lyubimtsev [21] and others mention monetary stage. } \\
\text { In the process of production stage the product and its cost are created and formed while in the } \\
\text { process of circulation there is only the change of the forms of value (use value, cash value). }\end{array}$ \\
\hline $\begin{array}{l}\text { Abalkin L.I., Arakelyan } \\
\text { A.A., Vilensky M.A., } \\
\text { Ivanov Yu.M., Kovalyov } \\
\text { A.F., Kurenkov Yu.V., } \\
\text { Malygin A.A., Poltorygin } \\
\text { V.K., Khoruzhyi L.A. }\end{array}$ & The definition of the concept of extended, simple and contracted reproduction of basic assets. \\
\hline $\begin{array}{l}\text { Abramov S.I., Amosov } \\
\text { A.I., Andrianov V.D., } \\
\text { Vodyanov A., } \\
\text { Goloviznina O.A., } \\
\text { Gorbunov A.A., Gubanov } \\
\text { S.S., Zhdanov S.A., } \\
\quad \text { Tunin G.A. } \\
\end{array}$ & $\begin{array}{l}\text { Problems of basic assets reproduction at industrial enterprises in modern conditions: limit of } \\
\text { enterprise's internal funds, low investment appeal of the most industries, insufficient support of } \\
\text { the government. Strategic and tactical directions of those problems solution are considered. }\end{array}$ \\
\hline
\end{tabular}

It is necessary to underline that exactly the reproduction of basic assets of industry providing their full renewal can provide neoindustrial transformation of economics.

We put forward a hypothesis that in modern conditions growth rate of investment in basic capital at industry is insufficient for capital assets renewal. Perm Krai, the economy of which has the pronounced industrial specialization can be the example for testing this hypothesis.

In the process of testing there were issues the challenge to define the growth rates of investment in the basic capital of industry, growth rates of capital renewals, growth rates of Perm Krai industrial basic assets depreciation. The following results were obtained.

The necessity of analyzing dynamics and structure of investments in the basic capital is conditioned by the fact that mass renewal of basic assets of industry is, first of all, the result of investments, which in its turn becomes the main factor of economic modernization and development. Let's calculate the investment growth rates according to the types of economic activity in Perm Krai industry. To eliminate the inflation component calculation is made on the base of stable prices of 2005 (Table III). 
Table 3. Growth rates of investment in basic capital according to the types of economic activity in Perm Krai industry, prices of $2005, \%$.

\begin{tabular}{|c|c|c|c|c|c|}
\hline KEA & $2009 / 2005$ & $2013 / 2005$ & $2013 / 2009$ & $\begin{array}{l}2014 / \\
2005\end{array}$ & $2014 / 2013$ \\
\hline $\begin{array}{l}\text { Investment in basic } \\
\text { capital }\end{array}$ & 113.7 & 139.3 & 122.5 & 141.3 & 101.4 \\
\hline $\begin{array}{l}\text { Mining operations, } \\
\text { including: }\end{array}$ & 134.5 & 199.9 & 148.6 & 211.9 & 106.0 \\
\hline Fuel and energy & 138.8 & 199.9 & 131.0 & 217.6 & 127.8 \\
\hline $\begin{array}{c}\text { Apart from fuel and } \\
\text { energy }\end{array}$ & 99.2 & 199.1 & 116.2 & 166.2 & 116.9 \\
\hline $\begin{array}{l}\text { Processing industries, } \\
\text { including: }\end{array}$ & 121.8 & 171.7 & 141.1 & 171.6 & 99.9 \\
\hline $\begin{array}{c}\text { Production of food } \\
\text { including drinks and } \\
\text { tobaccos }\end{array}$ & 88.5 & 97.1 & 109.7 & 101.9 & 104.9 \\
\hline $\begin{array}{c}\text { Textile and clothing } \\
\text { manufacture }\end{array}$ & 132.9 & 194.7 & 146.5 & 263.1 & 135.1 \\
\hline $\begin{array}{l}\text { Woodworking and wood } \\
\text { articles production }\end{array}$ & 86.0 & 79.1 & 92.0 & 73.7 & 93.1 \\
\hline $\begin{array}{c}\text { Pulp-and-paper } \\
\text { production; publishing } \\
\text { activity and printing } \\
\text { industry }\end{array}$ & 83.0 & 97.4 & 117.3 & 75.4 & 77.4 \\
\hline Coke and oil industry & 213.5 & 560.2 & 262.3 & 574.2 & 102.5 \\
\hline Chemical production & 118.6 & 189.2 & 159.6 & 190.0 & 100.4 \\
\hline $\begin{array}{c}\text { Rubber and plastic } \\
\text { products manufacture }\end{array}$ & 103.4 & 99.3 & 96.0 & 83.5 & 84.1 \\
\hline $\begin{array}{l}\text { Production of non-metal } \\
\text { mineral products }\end{array}$ & 148.9 & 140.5 & 94.4 & 112.1 & 79.8 \\
\hline $\begin{array}{c}\text { Metallurgical } \\
\text { production, final metal } \\
\text { products } \\
\end{array}$ & 110.8 & 102.7 & 92.7 & 92.7 & 90.2 \\
\hline $\begin{array}{c}\text { Machinery and } \\
\text { equipment production }\end{array}$ & 111.1 & 204.2 & 183.8 & 218.5 & 107.0 \\
\hline $\begin{array}{l}\text { Electric, electronic and } \\
\text { optic equipment } \\
\text { production }\end{array}$ & 111.2 & 158.4 & 142.4 & 148.6 & 93.8 \\
\hline $\begin{array}{l}\text { Production of transport } \\
\text { vehicles and equipment }\end{array}$ & 170.7 & 280.6 & 164.4 & 327.5 & 116.7 \\
\hline Other productions & 87.2 & 129.6 & 148.7 & 158.8 & 122.6 \\
\hline
\end{tabular}

Table III shows that dynamics of investment in basic capital by the types of activity in the period of 2005 2014 is uneven in whole.

During the analyzed decade (2004-1014) growth rates of investment in basic capital amounted to $141,3 \%$, including: in mining operations $-211,9 \%$, in processing industries $-171,6 \%$. If the mining sector demonstrated growth in all KEA (Kinds of Economic Activity) being the parts of it, the achievement of higher growth rates in processing industries was restrained by such branches as woodworking and wood articles production $(73,7 \%)$; pulp-and-paper production, publishing activity and printing industry $(75,4 \%)$; rubber and plastic products manufacture $(83,5 \%)$; metallurgical production and final metal products manufacture $(92,7 \%)$. These results confirm the concept of slow development of processing industries comparing to mining ones.

The situation emerged in mining operations is more favourable than in processing industries in whole. First of all it is expressed in the fact that growth rates of investment in basic capital of mining sector during the period of crisis exceeded the indicator of processing sector $(134,5 \%$ against $121,8 \%)$. Restoration of mining industry occurred much faster: growth in 2013 with respect to $2009-148,6 \%$, while the processing industries showed the growth amounted to $141,1 \%$. Moreover, in 2014 mining sector showed positive increase of $6,0 \%$ with respect to 2013 while the processing sector presented some negative growth of $0,1 \%$.

A low growth rate of investment in basic capital in 2014 with respect to 2013 was observed in key industries of Perm Krai. In 2014 chemical production showed the growth of $100,4 \%$; growth in coke and oil industry amounted only to $102,5 \%$.

Relatively positive dynamics was shown by fuel and energy industries, textile and clothing manufacture where growth rates of investment in basic capital in 2014 in comparison with 2013 amounted to $127,8 \%$ and $135,1 \%$ correspondingly.

Economic potential and character of basic assets renewal at industry are indicated by the factor of renovation and wear of basic assets (Table IV-V). 
Table 4. Growth rate of the factor of renewal of Perm Krai industry's basic capital, $\%$.

\begin{tabular}{|c|c|c|c|c|c|}
\hline KEA & $\begin{array}{c}\mathbf{2 0 0 9 /} \\
\mathbf{2 0 0 5}\end{array}$ & $\begin{array}{c}\mathbf{2 0 1 3} / \\
\mathbf{2 0 0 5}\end{array}$ & $\begin{array}{c}\mathbf{2 0 1 3} / \\
\mathbf{2 0 0 9}\end{array}$ & $\begin{array}{c}\mathbf{2 0 1 4} / \\
\mathbf{2 0 0 5}\end{array}$ & $\begin{array}{c}\mathbf{2 0 1 4} / \\
\mathbf{2 0 1 3}\end{array}$ \\
\hline $\begin{array}{c}\text { In all KEA, } \\
\text { including: }\end{array}$ & 113.3 & 135.6 & 119.6 & 131.1 & 96.7 \\
\hline $\begin{array}{c}\text { Mining } \\
\text { operations }\end{array}$ & 136.1 & 135.3 & 99.4 & 134.5 & 99.4 \\
\hline $\begin{array}{c}\text { Processing } \\
\text { industries }\end{array}$ & 93.7 & 98.2 & 104.8 & 102.7 & 104.6 \\
\hline
\end{tabular}

a. calculated by the authors according to the information of Federal agency of state statistics,

Analyzing the factor of renewal which characterizes the state of basic assets of Perm Krai industrial enterprises we see that negative tendencies of the Russian economy development have the farthest influence on processing industries: in 2009 growth rate of renewal coefficient amounted to $93,7 \%$. And on the contrary, they influenced positively on mining operations $(136,1 \%)$ in the context of this indicator analysis.

During 2005-2014 it was observed low growth rate of renewal coefficient in processing industry amounted to $102,7 \%$, which is less than the average regional indicator $(131,1 \%)$. On the contrary, mining sector has the indicator which is higher than the average regional level $-134,5$

Low rates of attracting basic capital define the process of basic assets ageing. Estimation of the basic assets deterioration in Perm Krai is given in Table V.

Table 5. Growth rate of basic capital deterioration in Perm Krai industry, \%.

\begin{tabular}{|c|c|c|c|c|c|}
\hline KEA & $\begin{array}{c}\mathbf{2 0 0 9} / \\
\mathbf{2 0 0 5}\end{array}$ & $\begin{array}{c}\mathbf{2 0 1 3} / \\
\mathbf{2 0 0 5}\end{array}$ & $\begin{array}{c}\mathbf{2 0 1 3} / \\
\mathbf{2 0 0 9}\end{array}$ & $\begin{array}{c}\mathbf{2 0 1 4} / \\
\mathbf{2 0 0 5}\end{array}$ & $\begin{array}{c}\mathbf{2 0 1 4} / \\
\mathbf{2 0 1 3}\end{array}$ \\
\hline $\begin{array}{c}\text { In all KEA, } \\
\text { including: }\end{array}$ & 111.2 & 117.6 & 105.7 & 118.9 & 101.1 \\
\hline $\begin{array}{c}\text { Mining } \\
\text { operations }\end{array}$ & 94.1 & 94.5 & 100.4 & 85.4 & 90.4 \\
\hline $\begin{array}{c}\text { Processing } \\
\text { industries }\end{array}$ & 107.5 & 118.1 & 109.8 & 116.2 & 98.4 \\
\hline
\end{tabular}

b. calculated by the authors according to the information of Federal agency of state statistics, Perm Krai department [23]

Analysis of the calculation results testifies sufficiently high growth rates of basic assets deterioration in the regional industry in whole, i.e. it shows the conservation of negative wear accumulation tendencies.

In the considered period of time more favourable tendency by the indicator of basic assets deterioration has been emerged in mining industry than in processing one. The growth rate of the basic capital wear in these branches has been lower for the decade than on the average in the region - $118,9 \%$. There are better indicators in the mining sector: growth rate of basic capital deterioration reduced by $16,6 \%$, and at the same time the processing sector demonstrated the increase of wear by $16,2 \%$.

Considering the indicators of 2014 in comparison with 2013 it is necessary to mention positive tendencies in mining and processing industries where the growth rate of deterioration level reduced by $9,6 \%$ and $1,6 \%$ correspondingly. The growth rate of deterioration coefficient in mining and processing industries in 2014 with respect to the previous year (90,4\% and $98,4 \%$ correspondingly) takes on a value lower than the regional average $(101,1 \%)$, and at that it is the characteristic feature of the indicators of 2009 in comparison with 2005.

When the share of worn basic assets is considerable economy incurs sufficient loss: first, ageing of buildings, constructions and equipment demands greater placement of funds in capital repairs; second, old facilities decrease products and services competitiveness, and technological backwardness involves production unprofitability.

In comparison of the diagrams presented in Fig. 1 and illustrating growth rates of key indicators of basic assets reproduction in Perm Krai industry it can be mentioned that growth rates of investment in basic capital is insufficient for mass renewal of basic assets. It is especially pronounced in processing industry. So, the investigation carried out by the authors confirmed their hypothesis.

Growth rates of investment in basic capital, \%

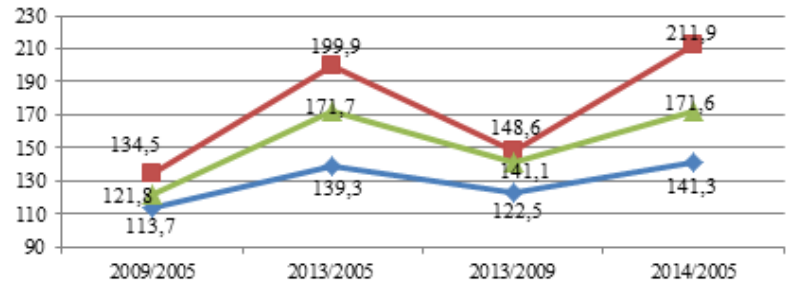

Growth rates of basic assets renewal coefficient, \%

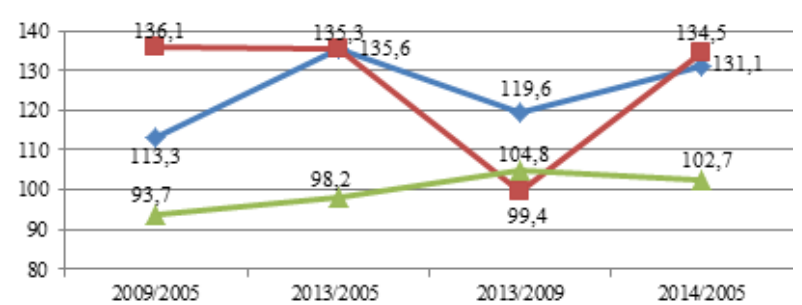

Growth rates of basic assets deterioration, \%

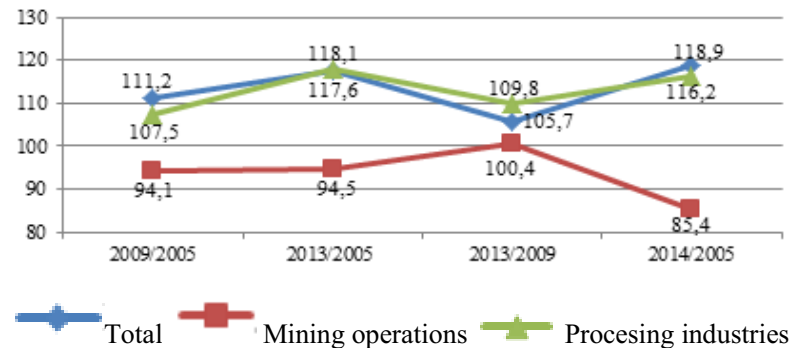

Fig. 1. Growth rates of key indicators of basic assets reproduction in Perm Krai industry.

Results of the research show that in Perm Krai the growth rate of investment in basic capital reduces while the level of deterioration of basic assets becomes higher. At that the situation in mining and processing industries is different: in mining industry it is more favourable while in processing one it is less favourable. At the same time the processes of reproduction in processing industries, and primarily in engineering are the key factor for neoindustrial transformation. 
Insufficient growth rate of investment in basic capital being an obstacle for the efficient renewal of industrial basic assets forms the stable tendency of basic assets' deterioration increase in processing industry of the region, and this is the serious barrier for realizing neoindustrial transformation of economy.

The results of this study have practical value consisting in the fact that the analysis of the processes of reproduction which occur in the regional industry showed the necessity of enlarged investing of basic assets in processing industry in the nearest 2-3 years in order to provide their mass renewal. Relying on these results the following practical recommendations to the local bodies can be given:

- it is required from authorities to maintain investment activity of processing industries, to organize purposeful work of favourable investment climate formation in the region;

- it is necessary to promote investment in modern startups, to create favourable conditions for them.

On the assumption of this it is thought to be reasonable the realization of public promotion of parallel processes: firstly, removal of worn facilities from economic operation and secondly, increase of investment in basic assets aimed at renewal of conventional industrial production and conferring high-tech character to the fields identifying basic competences of industrial region corresponding to the neoindustrial model of economy.

Thus, the idea of neoindustrialization should transform to the reasonable industrial policy, to the roadmap of movement towards principally new industrial base consisting of complex and highly efficient technological renewal of enterprises' basic assets. And this demands the realization of managerial efforts aimed at support of investment activity of business.

\section{References}

1. A.R. Belousov, Limits of self-development. http://old.russ.ru/antolog/inoe/belous_o.htm\#top.

2. A.R. Belousov, Evolution of the Russian economy's reproduction system: from crisis to development (MAKS Press, Moscow, 2006)

3. S.Yu. Glazyev, Crisis is of artificial character. http://communitarian.ru/novosti/ekonomika/sergey glazev_krizis_nosit_rukotvornyy_harakter_2711201 $4 /$.
4. Key statements of RF President in the message to the parliament. http://tass.ru/poslanie-prezidentafederalnomu-sobraniyu.

5. J. Helbreit, Modern industrial society (AST, Moscow, 2004)

6. D. Bell, Forthcoming post-industrial society. Experience of social prediction (Academia, Moscow, 2004)

7. E. Toffler, The third wave (AST, Moscow, 2010)

8. E. Toffler, Shock of the future (AST Ltd., Moscow, 2003)

9. M. Kastels, Informational epoch. Economics, society and culture (SE HSE, Moscow, 2000)

10. S.S. Gubanov, Sovereign break. Neoindustrialization of Russia and vertical integration (Knizhny Mir, Moscow, 2012)

11. S.S. Gubanov, Economist. Russia, 9, 3-27 (2008)

12. V.L. Inozemtsev, Russia in global policy, 6, 85-98 (2011)

13. O.A. Romanova, Region economics, 2, 70-80 (2012)

14. Account dictionary. Basic assets. http://www.slovar.plib.ru/dictionary/d30/7785.html.

15. A. Smith, Study of peoples' nature and wealth (Eksmo, Moscow, 2007)

16. D. Ricardo, Fundamentals of political economy and taxation (Gospolitizdat, Moscow, 1955)

17. K. Marx, Capital. Criticism of political economy (Politizdat, Moscow, 1967)

18. K Marx, F. Engels, Collected works. http://www.informaxinc.ru/lib/marx/31.html.

19. D.A. Baranov, Theory of amortization and technological progress (Gosfinizdat, Moscow, 1965)

20. S.K. Korkin, Revolution of basic assets in socialist reproduction (Kazan Univ., Kazan, 1990)

21. Yu.I. Lyubimtsev, The cycle of reproduction and amortization of basic assets (Economica, Moscow, 1973)

22. United interagency information-statistics system. http://www.fedstat.ru.

23. Perm Krai federal service of state statistics. http://permstat.ru. 